\title{
10 \\ THE DESIGN OF TAX INCENTIVES FOR GIVING
}

\author{
Richard Steinberg
}

Ever since Vickrey (1962) first proposed the treasury efficiency criterion for evaluating the charitable giving tax deduction in the United States, economists have argued over whether personal giving should receive special treatment through the personal income tax system and, if so, what form that treatment should take. It is time to bring these disparate analyses from economics and selected other fields together, and that is my goal in this chapter on tax design. This chapter focuses on the design of taxes levied against personal income and consumption ${ }^{1}-$ the tax treatment of corporations and other profit-distributing organizations, nonprofit organizations (that is, organizations that cannot distribute their profits), and charitable bequests is beyond the scope of the chapter. I focus on considerations of efficiency, fairness, and legitimacy and omit important administrative considerations (processing and enforcement costs, enforceability of restrictions, and taxpayer compliance costs) in the interest of space.

In the first section, I discuss some results that are commonly believed to be correct but are in fact misleading, incomplete, or just plain wrong. In the next section, I catalog four elements of tax incentive design and gather the many variations of each element that have been used or proposed in the United States. I conclude with some approaches to choosing among the available options. While I am primarily concerned with economic aspects of tax design, tax systems affect the perceived fairness and legitimacy of government, and I discuss these impacts within the limits of my expertise.

\section{What's wrong: accepted wisdom that misleads}

In this section, I discuss four erroneous, incomplete, or misleading approaches that are commonly cited as correct. First, the literature shows that tax deductions for charitable giving provide a greater subsidy to the rich than to the poor. This conclusion is correct but incomplete and misleading. Second, the literature asserts that a tax incentive is treasury efficient (that is, results in an increase in donations that exceeds the loss of tax revenue) if and only if the price elasticity of giving is greater than one (in absolute value). This conclusion is incorrect. Third, the literature asserts that when giving passes the proper test for treasury efficiency, tax incentives for giving are socially efficient. They are not. Finally, it is commonly believed, at least among economists, that efficiency is the primary objective of public policy. As most non-economists know, this is an exaggeration, and I discuss other important objectives for tax policy. 


\section{Pro-rich aspects of charitable tax deductions}

In a progressive income tax, the average tax rate $^{2}$ increases with the amount of income. Progressivity is implemented through some combination of a zero bracket (the first few dollars of income on which no tax is owed) and marginal tax rates ${ }^{3}$ that increase with income. In the United States, the zero bracket has been replaced by the "standard deduction," which is $\$ 24,400^{4}$ in tax year 2019 . Those with incomes of less than $\$ 24,400$ face a zero marginal and average tax rate and pay no income tax. The marginal tax rate is $10 \%$ for income between $\$ 24,400$ and $\$ 43,450$ and rises in a series of steps to $37 \%$ for income exceeding $\$ 624,400$. Taxpayers can reject the standard deduction and instead list their actual expenditures on certain tax-favored items including charitable donations (itemized deductions) whenever they calculate this would reduce their tax burden.

Those who itemize reduce their taxable income (and hence their taxes) in proportion to the amount given, but taxes do not depend on the amount of donations made by non-itemizers. ${ }^{5}$ We measure the impact of these tax considerations using the "tax price of donations," which represents the net cost to the taxpayer of a dollar of charitable giving. This tax-price is $\$ 1$ for nonitemizers, but is reduced to $\$ 1-m$, where $m$ is the marginal tax rate, for itemizers. ${ }^{6}$ For example, when an itemizing taxpayer in the $37 \%$ bracket gives $\$ 1,000$, her taxable income is reduced by $\$ 1,000$, so she avoids $\$ 370$ in taxes. The net cost to the high-income taxpayer of giving $\$ 1,000$ is $\$ 630$, so the tax-price (per dollar) is $\$ 0.63$.

The tax-price of giving declines as income rises for two reasons. First, those with more income are more likely to itemize and hence receive a price reduction. Second, the marginal tax rate increases as income rises, causing further reductions in the tax-price for itemizers as they move up through the income distribution.

This pattern of subsidizing the wealthy in a "bizarre upside-down fashion" (Surrey 1973: 229-230) results in a "plutocratic bias" (Vickrey 1947: 131). Precisely what is wrong with this pattern is not made clear in some publications, but it seems to offend notions of distributional justice based on norms of progressivity. Plutocratic bias may be objectionable on other grounds, but this is the misleading part of the claim, because tax deductions are not generally regressive.

Tax codes are too complex with too many discontinuities to fully characterize when the deduction is progressive or regressive, so I provide a few examples to illustrate my point in Figure 10.1. In all the examples, I assume that the tax code incorporates the simplest linear progressive structure ${ }^{7}$ and calculate average tax rates with and without a charitable donations deduction. To further simplify, I set the standard deduction to $\$ 0$ so that every donor itemizes. Finally, I make the very reasonable assumption that the deduction is not refundable, which means that anytime the formula suggests a negative amount of tax (government paying the taxpayer), that number is replaced by $\$ 0$.

The usual definition of a progressive tax is that the average tax rate rises with income. I report average tax rates but also another measure, consumption as a share of gross income. Absent donations, the average tax rate plus consumption as a share of gross income add up to one, so that an equivalent definition of progressivity is that the consumption share decreases with added income. But are donations part of consumption, used to purchase "warm glow," or are donations a part of income that is not available to the donor for consumption? If donations are part of consumption, both measures of progressivity tell the same story, but otherwise, the tax system can be regressive by the first measure and progressive by the second. I therefore report both measures in Figure 10.1.

The first table in Figure 10.1 is the base case, with numbers that seemed plausible plucked out of thin air. The first two columns, containing income and donations, show the behavior 


\begin{tabular}{|c|c|c|c|c|c|c|c|}
\hline \multicolumn{2}{|c|}{ Base Case } & \multicolumn{3}{|c|}{ Without Deductibility } & \multicolumn{3}{|c|}{ With Deductibility } \\
\hline Income & Donations & $\operatorname{Tax}$ & $\begin{array}{l}\text { Average } \\
\text { tax rate }\end{array}$ & $\begin{array}{l}\text { Consumption as } \\
\text { a share of income }\end{array}$ & $\operatorname{Tax}$ & $\begin{array}{l}\text { Average } \\
\text { tax rate }\end{array}$ & $\begin{array}{l}\text { Consumption as } \\
\text { a share of income }\end{array}$ \\
\hline$\$ 50$ & $\$ 5$ & $\$ 0$ & 0 & 0.9 & $\$ 0$ & 0 & 0.9 \\
\hline$\$ 100$ & $\$ 15$ & $\$ 0$ & 0 & 0.85 & $\$ 0$ & 0 & 0.85 \\
\hline$\$ 200$ & $\$ 50$ & $\$ 30$ & 0.15 & 0.6 & $\$ 15$ & 0.075 & 0.675 \\
\hline$\$ 400$ & 150 & $\$ 90$ & 0.225 & 0.4 & $\$ 45$ & 0.1125 & 0.5125 \\
\hline
\end{tabular}

\begin{tabular}{|c|c|c|c|c|c|c|c|}
\hline \multicolumn{2}{|c|}{ Double Donations } & \multicolumn{3}{|c|}{ Without Deductibility } & \multicolumn{3}{|c|}{ With Deductibility } \\
\hline Income & Donations & $\operatorname{Tax}$ & $\begin{array}{l}\text { Average } \\
\text { tax rate }\end{array}$ & $\begin{array}{l}\text { Consumption as } \\
\text { a share of income }\end{array}$ & $\operatorname{Tax}$ & $\begin{array}{l}\text { Average } \\
\text { tax rate }\end{array}$ & $\begin{array}{l}\text { Consumption as } \\
\text { a share of income }\end{array}$ \\
\hline$\$ 50$ & $\$ 10$ & $\$ 0$ & 0 & 0.8 & $\$ 0$ & 0 & 0.8 \\
\hline$\$ 100$ & $\$ 30$ & $\$ 0$ & 0 & 0.7 & $\$ 0$ & 0 & 0.7 \\
\hline$\$ 200$ & $\$ 100$ & $\$ 30$ & 0.15 & 0.35 & $\$ 0$ & 0 & 0.5 \\
\hline$\$ 400$ & $\$ 300$ & $\$ 90$ & 0.225 & 0.025 & $\$ 0$ & 0 & 0.25 \\
\hline
\end{tabular}

\begin{tabular}{|c|c|c|c|c|c|c|c|}
\hline \multicolumn{2}{|c|}{ Income Elastic ${ }^{1}$} & \multicolumn{3}{|c|}{ Without Deductibility } & \multicolumn{3}{|c|}{ With Deductibility } \\
\hline Income & Donations & $\operatorname{Tax}$ & $\begin{array}{l}\text { Average } \\
\text { tax rate }\end{array}$ & $\begin{array}{l}\text { Consumption as } \\
\text { a share of income }\end{array}$ & $\operatorname{Tax}$ & $\begin{array}{l}\text { Average } \\
\text { tax rate }\end{array}$ & $\begin{array}{l}\text { Consumption as } \\
\text { a share of income }\end{array}$ \\
\hline$\$ 50$ & $\$ 5$ & $\$ 0$ & 0 & 0.9 & $\$ 0$ & 0 & 0.9 \\
\hline$\$ 100$ & $\$ 20$ & $\$ 0$ & 0 & 0.8 & $\$ 0$ & 0 & 0.8 \\
\hline$\$ 200$ & $\$ 80$ & $\$ 30$ & 0.15 & 0.45 & $\$ 6$ & 0.03 & 0.57 \\
\hline$\$ 400$ & $\$ 360$ & $\$ 90$ & 0.225 & -0.125 & $\$ 0$ & 0 & 0.1 \\
\hline
\end{tabular}

\begin{tabular}{|c|c|c|c|c|c|c|c|}
\hline \multicolumn{2}{|c|}{ Income Inelastic ${ }^{2}$} & \multicolumn{3}{|c|}{ Without Deductibility } & \multicolumn{3}{|c|}{ With Deductibility } \\
\hline Income & Donations & $\operatorname{Tax}$ & $\begin{array}{l}\text { Average } \\
\text { tax rate }\end{array}$ & $\begin{array}{l}\text { Consumption as } \\
\text { a share of income }\end{array}$ & $\operatorname{Tax}$ & $\begin{array}{l}\text { Average } \\
\text { tax rate }\end{array}$ & $\begin{array}{l}\text { Consumption as } \\
\text { a share of income }\end{array}$ \\
\hline$\$ 50$ & $\$ 5$ & $\$ 0$ & 0 & 0.9 & $\$ 0$ & 0 & 0.9 \\
\hline$\$ 100$ & $\$ 7.5$ & $\$ 0$ & 0 & 0.925 & $\$ 0$ & 0 & 0.925 \\
\hline$\$ 200$ & $\$ 11.25$ & $\$ 30$ & 0.15 & 0.794 & $\$ 26.62$ & 0.133 & 0.811 \\
\hline$\$ 400$ & $\$ 16.87$ & $\$ 90$ & 0.225 & 0.733 & $\$ 84.94$ & 0.212 & 0.745 \\
\hline
\end{tabular}

Notes:

1 Assuming the income elasticity of donations is 2

2 Assuming the income elasticity of donations is 0.5

Figure 10.1 The charitable donations tax deduction need not be regressive

of four different taxpayers (rows) arranged in order of income. The next three columns report taxes owed and the two measures of progressivity when charitable donations are not deductible from gross income. This tax is clearly progressive under either method when donations are not deductible. The last three columns replicate these calculations when donations are deductible. Despite the lower price of giving for itemizers, the tax system remains progressive, with increasing average tax rates and decreasing consumption shares. 
The next three tables vary the amount of donations at each income level to show that the progressivity conclusion is somewhat robust. The second table doubles the amount of donations at each income level to see whether tax deductions are regressive for the most generous. They are not. Without deductibility, we confirm that the linear income tax is progressive. With deductibility, our four taxpayers pay zero in taxes, so the average tax rate is constant (neither progressive nor regressive). However, consumption as a share of income does decline dramatically with income, so the system remains progressive by this measure. The last two tables vary donations so that the income elasticity of donations is elastic and equal to 2 , then inelastic with elasticity equal to $1 / 2$. In the elastic case under deductibility, the average tax rate is stable at zero, then jumps to a small positive number, then returns to zero, indicating that it is possible that the deduction makes the tax regressive over some income ranges using the traditional measure of progressivity. However, even here, the system remains progressive in terms of consumption. ${ }^{8}$ Finally, when giving is income inelastic, deductibility has a much smaller effect on progressivity by both measures, and the system is approximately equally progressive with and without deductibility of donations.

\section{The treasury efficiency test is wrong}

Early writers such as Vickrey (1962) worried whether the amount of giving stimulated by a tax deduction or credit was large enough to justify the foregone taxes. Subsequent work located these concerns in the "tax expenditure" framework, where government can collect taxes to directly subsidize charity or offer indirect subsidies in the form of tax breaks that encourage increased donations. In this framework, the indirect route is superior ("treasury efficient") if the added donations exceed the loss in tax collections, which happens whenever tax credits or deductions for charitable donations are employed and the (absolute value of the) price elasticity of giving exceeds unity (e.g., Clotfelter 1985). ${ }^{9}$ As a result, hundreds of empirical studies focus on obtaining valid estimates of the price elasticity of giving, almost all of which report tests of whether the elasticity is greater than one. Recent surveys of this literature continue to report this as the proper test of treasury efficiency (e.g., Bakija 2013; Monnet and Panizza 2017). But this is not the proper way to test for treasury efficiency.

Feldstein (1980) was the first to recognize that the traditional test ignored interactions between direct government spending and charitable donations. Simply put, government spending changes the volume of charitable donations for similar goods and services - "crowding out" (when donations fall in response to government spending) or "crowding in" (when government spending increases donations) (e.g., Steinberg 1987; Andreoni 1989; Ribar and Wilhelm 2002). However, Feldstein made some technical errors, and so the proper test for treasury efficiency was devised by Roberts (1987). He found that the critical price elasticity for treasury efficiency is less than unity when there is crowding out and greater than unity when there is crowding in.

Why is this true? Taxes create economic distortions, so government policy should look for the cheapest route to financing a given expenditure on collective goods. Equivalently, government should maximize "bang for the buck." Collective-good expenditure comes from both government spending and charitable donations, and charitable donations are provided even when the government offers no tax subsidies. Suppose first that government spending crowds out charitable donations dollar-for-dollar (100\% crowdout). Then direct government subsidies accomplish nothing - each time government grants increase donations fall by the same amount and total spending on the collective good does not change. ${ }^{10}$ Indirect subsidies accomplish something provided the price elasticity of donations is not zero, and something is better than nothing. Hence, any elasticity greater than 0 suffices to show that tax breaks are more treasury 


\section{Richard Steinberg}

efficient than direct government spending. The traditional rule, with a critical elasticity of unity is only correct when there is zero crowdout.

Empirical studies provide a complex picture of the extent of crowdout. De Wit and Bekkers's (2017) meta-analysis found that about $2 / 3$ of the studies found crowding out and $1 / 3$ found crowding in. The form of government direct support seemed to matter, as direct government production of collective goods has a larger effect than government grants to nonprofits. Crowdout estimates produced from experimental data were many times larger than those produced from natural data. This is consistent with the results of Ribar and Wilhelm (2002), whose theory showed that the size of the donor group matters, and with Ottoni-Wilhelm, Vesterlund, and Xie (2017), who found that crowdout decreases with output. Finally, the studies use different techniques to deal with econometric problems such as endogeneity bias, and De Wit and Bekkers found that this also affects estimates.

So, are deductions or credits treasury efficient by the proper test? The question is poorly posed, because there is not a single price elasticity of giving for all kinds of giving and for giving to all kinds of causes (e.g., Brooks 2007; Backus 2010; Hossain and Lamb 2012; Zampelli and Yen 2017), nor is there a single level of crowding out. Unless governments are willing and able to differentiate credits across these many factors accordingly, the concept of treasury efficiency is far more limited than previously thought.

\section{Treasury efficiency is not social efficiency}

Treasury efficiency was conceived as a simple and operational test to compare direct and indirect support for nonprofit organizations, but it measures social efficiency only under some very special circumstances. Other times, it can be massively misleading, because it supports a deduction or credit in cases where three threshold questions have not been answered: Should the nonprofit be subsidized? Should the subsidy apply to private donations? Should we subsidize organizations or activities? Finally, treasury efficiency does not suffice to determine the best subsidy rate. For all these reasons, we need a full-fledged measure of social efficiency for tax system design.

When used by an economist, efficiency has a precise mathematical definition that is more stringent than use of the word in common discourse would suggest. Efficiency is based on the outcomes throughout the entire economy which consists of all available resources, all the ways resources can be transformed into goods, all the individuals present, and all the ways of dividing each good among consumers. Economy A Pareto-dominates economy B if no individual in that economy prefers B and at least one individual prefers A. Economy A is efficient (synonyms: Pareto-optimal, socially efficient) if it is feasible (can be produced from available resources) and all economies that Pareto-dominate A are not feasible. Equivalently, an economy is socially efficient if the only way to make any consumer better off in her own estimation requires that at least one other consumer be made worse off.

In common discourse, efficiency means that resources are not wasted in production of goods or services. Social efficiency has additional requirements: that the right mixture of goods be produced and that each consumer's bundle of goods match that consumer's preferences. When the economy is inefficient, there is a feasible way to help people without hurting anyone else, and most agree that society should do so. But there are many socially efficient economies that cannot be mutually compared by the Pareto standard because one person prefers socially efficient economy A and another prefers socially efficient economy B. In effect, the various socially efficient economies differ in the distribution of income, so a theory of distributive justice is needed to determine the best efficient economy. Mathematically, efficiency and equity are combined in the form of a social welfare function, which provides a complete and transitive rank 
order over economies so that you can identify the social optimum (the best economy). Theories of distributive justice enter the function in the form of distributional weights for comparing monetary equivalent gains of one consumer with losses of another. There are substantial disagreements over how egalitarian social welfare functions should be, but any view can be accommodated by this tool.

The sources of social inefficiency in economic equilibrium are called market failures. In the next subsections, I first detail two market failures relating to gifts and donations and discuss how these inefficiencies can be fixed by proper tax design. Both these problems relate to the fact that transfers of income are collectively consumed as benefits to the giver, other givers, and ultimate recipients. A pure collective good ${ }^{11}$ has two properties - nonrivalry (each unit of production can be enjoyed multiple consumers) and nonexcludability (once the good is made, it is not feasible to keep anyone from consuming it). Next, I turn to the treatment of charitable donations in the literature on socially optimal income taxes, which also incorporates other market failures affected by the tax treatment of donations. Finally, I return briefly to the threshold questions from a social welfare framework.

\section{A remediable market failure due to donor motivations}

Arrow (1972) noted a peculiarity about gift-giving and charitable donations - the act of giving is valuable to the donor independently of the consequences of that gift. This idea was developed further, most notably by Andreoni (1990) in his impure altruism model. Altruistic motives value the consequences of the gift, warm glow values the act of giving, and a donor with a mixture of both motivations is an impure altruist. Pure altruists want to others to be helped, but donations are inadequate because of the free-rider problem - one potential donor can enjoy the level of collective goods supported by other donors without personally contributing, and in any case the personal benefit of giving (enjoying a small increase in collective good provision) is far less that the benefits to the group (simultaneously enjoying that small increase). ${ }^{12}$ Warm glow reduces free-riding because non-donors must forgo the special personal benefit associated with personally giving. Kaplow (1995) found that there is a new kind of market failure due to warm-glow preferences. ${ }^{13}$ The failure is best illustrated with an example. Suppose Fred is considering a $\$ 10$ gift for Wanda. If he makes the gift, he receives warm glow because he feels better about himself for being so generous or because his prospects with the ladies have improved as he gets a reputation for being generous. If Fred's warm glow is equivalent to $\$ 15$ (that is, he would have to toss a coin to decide whether to accept $\$ 15$ additional income for not making the gift in place of the $\$ 10$ gift expenditure), then he makes the gift. The money-equivalent net benefit to Fred is $\$ 5$, the value of his warm glow minus the monetary cost of the gift. For simplicity, assume that Wanda's value of receiving the gift is $\$ 10 .{ }^{14}$ Both parties benefit from the exchange, no one else is harmed, and the outcome is socially efficient.

But suppose instead that Fred only receives $\$ 7.50$ in warm glow from giving the gift. Then he does not give Wanda the gift, but mutual gains would be possible if he did, so this outcome is inefficient. Government could fix this inefficiency by giving Fred a $\$ 3.00$ subsidy. Now, the sum of warm glow and subsidy exceeds the cost, Fred makes the gift and receives net benefits of $\$ 0.50$, and Wanda gets $\$ 10$. The sum of gains to Fred and Wanda exceeds the cost to the taxpayers who pay for the subsidy, so it is possible to redistribute gains so that Fred, Wanda, and the taxpayers are all better off. The subsidy is socially efficient if the sum of the net benefits exceeds the so-called dead-weight loss, the money-equivalent value of unintended harmful side-effects due to financing the subsidy. ${ }^{15}$ This provides a rationale for subsidizing charitable donations through the tax system, but Fred's gift was to a single person and not to 


\section{Richard Steinberg}

some charitable cause. Kaplow's (1995) argument would justify a tax deduction for any kind of gift motivated by warm glow.

\section{A remediable market failure in voluntary donations for a pure collective good}

Donative nonprofits, and even some commercial nonprofits, focus on providing pure collective goods. ${ }^{16}$ Helping people in need of income and services is a collective good for the community that cares about these people, so when one donor gives, other donors benefit. Educational institutions, ideally, help voters make better decisions, and the quality of government is collectively consumed. Religious institutions produce social capital, also collective. We have already commented on the free-rider problem, leading to underprovision of collective goods, but now we will take a different look at it.

Collective goods are a specific form of a broader market failure due to externalities. An externality is a side effect of a market transaction on those who were not parties to the transaction, such as pollution inhaled by my neighbors when I buy fossil-fuel electric power. Specifically, donations produce reciprocal external benefits (meaning if any member of the group donates, every member of the group benefits). Externality theory was developed by Arthur Cecil Pigou in 1920, and his proposed solutions are known as Pigouvian taxes and subsidies in his honor. Because donations produce external benefits, they should receive Pigouvian subsidies, and if the marginal subsidy rate (amount of additional subsidy provided to the last dollar donated) is set equal to the marginal external benefits (the sum across external beneficiaries of benefits resulting from the last dollar donated), the optimal quantity of donations will be provided.

It is unknown but extremely unlikely that the charitable deduction in the United States provides optimal Pigouvian subsidies, as the marginal subsidy rate is zero for non-itemizers and equal to various marginal tax rates for itemizers. This could be approximately optimal if non-itemizers supported charities without marginal external benefits and the highest-income taxpayers supported causes with the largest marginal external benefits, a dubious supposition. But a Pigouvian subsidy set too low still helps, moving the economy towards social efficiency. Unfortunately, if the subsidy rate is set sufficiently above the optimum, efficiency will be lower than it would be when unsubsidized. My own opinion is that the current system, crude as it is, is helpful from a Pigouvian standpoint but could be more helpful if there were an above-the-line charitable contributions deduction or if the deductions were replaced by tax credits set at the appropriate rate. ${ }^{17}$

\section{The optimal income tax treatment of donations}

Optimal tax structures maximize the social welfare produced within a class of tax structures, such as the optimal linear or nonlinear income tax or the optimal set of commodity taxes. Results depend on parameterized social weights embodying a particular notion of distributive justice and, without consensus on that, cannot be made operational. Nonetheless, the literature provides some guidance for policy makers concerned with tax design.

Saez (2004) considers a government that wants to maximize social welfare by choosing an amount to spend on public provision of a single collective good, an amount of money that accomplishes redistribution in the form of a uniform cash transfer to all households, and a subsidy rate for private donations in a linear tax on labor income that balances the budget. His formulation incorporates a warm-glow term reflecting Kaplow's (1995) concern, a Pigouviansubsidy term reflecting externalities, and a crowdout term reflecting Roberts's (1987) modeling of revenue interactions. He separately analyzes two polar cases (logical extremes spanning realistic 
cases), where the government-produced good is unrelated to the nonprofit good and where the two are identical.

In the first polar case, government produces a good that is unrelated to the good financed by donations. Then the crowdout term drops out (unrelated goods do not crowd each other in or out). The optimal subsidy rate increases with a) the magnitude of external benefits from the nonprofit good, b) the tax-price elasticity of giving, and c) the size of average weighted warmglow benefits. All else equal, when donations are sufficiently price inelastic, the optimal subsidy rate is negative - donations are taxed, not subsidized. This is because price inelastic goods can be taxed without substantially reducing the quantity of warm glow, with the tax revenues used to reduce the dead-weight loss resulting from distortions in the labor market. Social weights also matter. If the weights are sufficiently egalitarian (supportive of redistribution from rich to poor) and average weighted warm-glow benefits are high, then the optimal subsidy depends on whether the rich give disproportionately more than others. The optimal subsidy is smaller if the rich give disproportionately more and larger otherwise.

In the second polar case, the government provides exactly the same good as the nonprofits. Now the Pigouvian term drops out because government adjusts its direct spending to ensure that the sum of donations and government spending provides the optimal quantity of the collective good. Saez (2004) assumes that the price elasticity of giving is not constant but gets smaller (in absolute value) as the price decreases. ${ }^{18}$ To find the optimum subsidy rate, you increase the rate (decrease the price of giving) until the price elasticity reaches a critical value equal to $(1-$ marginal crowdout $) *(1-$ wtd.average marginal warm glow benefit $)$

Both parenthetic quantities are less than 1 (unless there is crowding-in), so their product is less than 1.

If we reformulate the proper and common tests for treasury efficiency when the price elasticity is a variable, then subsidy rates should be increased until the elasticity declines to equal 1 (by the common test for treasury efficiency) or $(1$ - marginal crowdout) (by the correct test). Thus, the suggested subsidy is largest in optimal tax theory, smaller by treasury efficiency, and smallest by the traditional misapplication of treasury efficiency. The three measures are the same only when marginal crowdout and marginal warm glow are zero.

Subsequent work has generalized the model in various ways. Diamond (2006) makes some different assumptions and considers the optimal nonlinear income tax. He makes a serious argument that although warm glow affects behavior, ${ }^{19}$ it should not be included in social welfare determination of the optimum. He then characterizes optimal taxes with and without warm glow in the social welfare function. Blumkin and Sadka (2007) consider a different form of warm glow stemming from status competition. At least in some settings, donors are motivated to give the largest donations because that comes with the highest level of status (Harbaugh 1998). Unlike the other reasons for warm glow, status is a zero-sum game. One individual's gain in status produces negative externalities in the form of lower status of others. Harbaugh focuses on how nonprofits can manipulate the status competition by creating elite categories of givers (e.g., "golden, silver, and bronze donors") that increase total giving, but Blumkin and Sadka take a different approach. Following the optimal tax literature tradition, government adjusts spending to maintain the optimal level of the collective good, so the positive externalities of giving vanish, the negative remain, and the proper Pigouvian solution is to tax donations. In contrast, preliminary work by Hungerman (2020) builds on Saez (2004) to analyze large gifts. He adds a measure of skewness in the distribution of gifts and finds that large subsidies are optimal even when giving is fairly price inelastic. Almunia et al. (2020) note that many donors do not claim their eligible donations on tax returns because the transaction costs exceed the tax benefits. They estimate an adjusted optimal subsidy rate using a structural model of tax reporting. 


\section{Richard Steinberg}

\section{The threshold questions}

Should nonprofits be subsidized by government in any fashion? From an efficiency standpoint, this depends on whether there are any market failures that could be addressed with subsidies. We have talked about two such market failures - the under-provision of collective goods and the under-provision of warm-glow-motivated gifts. ${ }^{20}$ Still, the picture is more complicated than just that. Government provides many non-tax subsidies that can make up for free-riderinduced shortages ${ }^{21}$ and also directly produces collective goods. If non-tax subsidies and/or government direct provision suffice to provide the optimal quantity of collective goods, then tax subsidies for giving would cause over-provision. ${ }^{22}$ The free-rider problem is reduced by warm glow and could be further reduced if nonprofits employed the provision-point mechanism or the raffle mechanism..$^{23}$ No free-rider problems affect sales of goods and services that do not create externalities, so the problem does not clearly apply to commercial charities (those that derive the bulk of their revenues from sales of goods and services, such as private nonprofit hospitals and universities). There may be other externalities associated with commercial nonprofits (such as effects of education on crime rates and democratic function) that call for Pigouvian adjustments to tax rates, but in other cases (advocacy), the positive and negative externalities may cancel out. In sum, there is an efficiency case for subsidizing some nonprofits and not others, and it is unclear whether uniform subsidies are, on balance, more helpful than harmful.

When subsidies should be given to nonprofit organizations, should they be in the form of favorable tax treatment for donations; favorable treatment under sales, property, corporate income, and other entity taxes; and/or favorable contracts, grants, and other non-tax benefits? Surprisingly little is known about this question. The optimal tax literature has not included mixtures of optimal personal and entity tax structures, typically selecting the optimum within a restricted class of tax instruments. Clotfelter (1988) took an early look at the harmful side effects of property, income, and sales tax exemptions but provided no empirical estimates to compare with the dead-weight losses stemming from adjustments to tax rates that hold tax revenues constant in the face of income tax deductions and credits. Steinberg and Bilodeau (1999) provide a debater's guide to the advantages and disadvantages of sales and property tax exemption, and scattered papers have been published since then, but none provide a comprehensive view.

The scant literature on the second question helps to answer the final threshold question should we subsidize organizations or activities? Income tax breaks encourage donations, which is the right choice for solving the problem of under-provision of warm-glow but is only a means to an end for solving the under-provision of collective goods and perhaps not the best means to that end. An alternative is a tax break based on organizational expenditures on collective goods such as the Historic Preservation Tax Credit, a 20\% tax credit for the rehabilitation of certified historic structures. ${ }^{24}$ Tax breaks like this more clearly ensure that revenues are spent on collective goods provision. ${ }^{25}$ The same is true for entity taxation. Exemption from a sales tax on purchases and/or sales directly subsidizes nonprofit commercial activity, only incidentally benefiting nonprofit provision of collective goods. Exemption from a property tax directly subsidizes nonprofit land use, and exemption from a corporate income tax (depending on details of the tax) directly subsidizes nonprofit use of capital. Instead, corporate taxes can be used to subsidize organizations, for-profit or nonprofit, for their expenditures on remedying market failures. This analysis only scratches the surface, and I mention it to raise more questions deserving attention. 


\section{Social optimality is overrated}

When a student is sent to the factory that turns him into an economist, he is exposed to social efficiency from day one and develops a natural bias that efficiency is the most important way to evaluate public policies. A few enlightened students move on to the distribution center, where they learn about distributional weights and social welfare functions and emerge thinking that social optimality is the most important thing. Rarely does the student move on to the human resources division of the firm, as Nobel Laureate Amartya Sen did, where he learns the fuzzier but truly important notion of human flourishing (Nussbaum 2011).

At the political scientist factory, distribution, just or otherwise, is where it's at. Every meaningful piece of legislation creates winners and losers, and legislation is passed when the winners are more numerous or more organized than the losers. Re-election sometimes depends on nothing more than that, but at other times, rewarding supporters and punishing oppositional members is seen as corrupt or unfair to the detriment of re-election. At the organizational theory factory, particularly in the sociology wing, graduates are trained to pay attention to the legitimacy and perceived legitimacy of institutions, organizations, and their decisions. The sociology and political science clubs may even focus on issues of power, fairness, and rights and may even conceive of a social contract granting and limiting personal rights in return for government's monopoly of legitimate coercive power.

What of the benevolent social planner, concerned with doing what's right for society? I am increasingly of the opinion that the other political science and organizational theory factories come closer to "doing what's right" than the economics factory does. I do not think that an efficient or socially optimal tax system makes as much difference to human flourishing as a fair tax system created by a political system widely regarded as legitimate. While the economic consequences of tax reform are quite significant in some cases, minor tweaks for optimality are hard to understand and are unlikely to be very salient in the minds of most citizens. The perceived unfairness and power maldistribution seen in the tax treatment of the very rich may be far more salient and important for human flourishing than efficiency. This is a reason to end the plutocratic bias resulting from the charitable tax deduction even if this form of subsidy is progressive and socially optimal.

\section{What's useful: a catalog of tax designs}

Literatures from different fields and disciplines focus on different dimensions of tax design. I think that an interdisciplinary catalog might prove useful to inform tax lawyers what economists are considering, to inform economists what tax lawyers are considering, and to help both understand the complexity of comprehensive tax reform. I consider four dimensions of tax policy: what kinds of entities are eligible to receive tax-favored donations with what restrictions on entity behavior, what kinds of donations are favored by the tax system, what kinds of restrictions are placed on taxpayers as a condition of eligibility to benefit from the tax-favored treatment, and what type of tax benefit is best.

\section{Eligible entities}

The common choice around the world restricts tax benefits to donations made to nonprofit entities. Gifts made to beggars on the street, to family members, and to unincorporated and informal community organizations are not eligible for support, but it is worth questioning 


\section{Richard Steinberg}

whether they should be. Now is a good time to consider the question, because there are two relatively new kinds of entities that perhaps should become eligible: donor-advised funds (which may be administered in a nonprofit community foundation or a nonprofit subsidiary of a for-profit investment company) and new hybrid corporate forms that combine features of nonprofit organizations with features of for-profits. In the United States, donations to donor-advised funds are generally tax deductible, but as donors retain large elements of control over how the funds are distributed, ${ }^{26}$ perhaps they should not be. Perhaps donors should not be allowed to deduct their contributions to a donor-advised fund but should be allowed to deduct their contributions from a donor-advised fund because that is when all control is relinquished.

A variety of hybrid forms have been created by recent legislation around the world. In the United States, we are experimenting with low-profit limited liability companies (L3Cs), B-corporations, and flexible purpose corporations. In the United Kingdom, there are community interest companies, and similar forms are popping up in other countries. These entities all distribute profits but with governance structures and restrictions designed to limit distribution and devote the rest of the profits to social purposes. There are also organizations that use a traditional corporate structure but call themselves social enterprises and try to devote some of their profits to providing collective goods (like reducing pollution). Currently, donations to hybrid organizations are not deductible and are not tax favored in any other way. Considering the threshold question regarding subsidizing donations or activities, this should be reconsidered.

U.S. nonprofits must restrict several kinds of activities to qualify for exemption from the Federal Corporate Income Tax. The federal nondistribution-of-profits tests differ in minor ways from those embodied in the various state corporation statutes, ${ }^{27}$ as does the list of eligible nonprofit purposes. ${ }^{28}$ Additional restrictions are placed on organizations seeking tax-favored donations. Political activities and advocacy are restricted, ${ }^{29}$ and organizations that provide commercial-type insurance as a substantial part of activities, ${ }^{30}$ as well as terrorist organizations, ${ }^{31}$ are denied exemption and deductibility. Nonprofit hospitals must meet additional requirements. ${ }^{32}$

Some writers talk about tax deduction as a privilege, not a right, and emphasize that in return for receiving this privilege, nonprofits must give up some control over activities and expenditures. I do not agree with denying advocacy on this ground (as denial of deductibility amounts to taxing the exercise of free-speech rights), but the policy question is a reasonable one - how far can the state go in restricting political speech, fundraising practices, support of controversial causes, executive compensation, or other practices because the organization has accepted deductible donations?

Policy makers have discussed limiting favorable tax treatment to various nonprofit subsectors. Political parties are already excluded, but sometimes there are proposals to restrict favorable tax treatment to nonprofits concerned with the poor and needy and exclude organizations like those in the arts and education that do not primarily benefit these groups. At the state level, there are many tax credits and deductions for gifts to named charities and to nonprofits in a particular field. Indiana, for example, provides state personal income tax filers with a $50 \%$ credit for contributions to public and private colleges and universities in the state, capped at $\$ 400$ (Indiana Department of Revenue 2020). All faculty are urged to donate and take this credit, and the university facilitates qualifying gifts that can be earmarked for the faculty donor's research and travel allowance, making a mockery of the restriction on donor control.

Although the matter is understudied, there is some evidence that special subsidies for charitable subsectors do not increase total giving. A laboratory experiment by Chatterjee et al. (2020) finds that targeted tax credits do not increase total giving; rather, they reallocate giving from ineligible to eligible organizations. An analysis of 46 tax credits in 23 states by Duquette 
et al. (2018) finds that estimated price elasticities do not statistically differ from zero, and the resulting confidence intervals rule out large effects.

\section{Eligible gifts}

In the United States and many other countries that favor donations, gifts of cash, appreciated assets, and in-kind goods and services made to eligible nonprofits receive favorable treatments. There are variations and controversies. For appreciated assets, should the appreciated value or original cost be favored? If the former, should any adjustments be made when the capital gains tax rate is different from the labor income tax rate? Should the appreciation portion of the asset gift be exempt from the capital gains tax when the asset is given directly but not when the asset is sold and the proceeds donated (the current practice in the United States)? How should inkind gifts be valued, particularly when the good is no longer traded in markets (when outdated models are donated) or when trading markets are thin (for example, when donating a painting to a museum)?

But it is also worthwhile to consider extending favorable treatment to gifts of blood and body organs, although I will not open that can of worms here. How about gifts of time? Some writers support explicit subsidization of volunteer hours, not recognizing that there are already implicit subsidies. To a first approximation, the donor's hourly opportunity cost of volunteering is the after-tax hourly wage rate, so the tax-price of volunteering is already reduced by one minus the marginal tax rate for both itemizers and nonitemizers. The relative price of money to time gifts is unaffected by taxes for itemizers (one minus the marginal tax rate cancels out) but is distorted in favor of time gifts for nonitemizers. This distortion would end if an above-theline charitable deduction were made permanent or the deduction were replaced by a tax credit.

Many donors donate by subscription, that is, through some system of regular automatic contributions (monthly, annually) for some period. Subscription giving is more valuable to recipient organizations, as it is more predictable and stable. Should subscription gifts be encouraged through more generous tax benefits? Others commit their future and posthumous giving through various kinds of trusts such as a split-interest trust, a charitable remainder trust, or a charitable lead trust. Should the tax treatment of charitable bequests be integrated with that for lifetime giving? Finally, some people make a current gift to create a private foundation. How should taxes regard these intertemporal donations?

\section{Eligible donors}

To benefit from a charitable deduction, one needs taxable income and a positive marginal tax rate. Low-income high-wealth taxpayers, if they make sufficiently large deductible gifts, would have negative taxable income. Under current law, the marginal tax-price of giving would be $\$ 1$ for these taxpayers, but it is possible to design a non-standard refundability provision (a negative tax obligation implies the government pays you) that would incentivize giving. The situation is slightly different with a tax credit, which is subtracted from taxes owed instead of from the income that is taxed. A constant credit rate could be used (e.g., subtract $50 \%$ of donations from taxes owed), and the tax-price of giving would be ( $\$ 1$ - the credit rate) or 50 cents when the credit rate is 0.5 . If the credit is nonrefundable, then the total credit is capped at taxable income, so the tax-price of giving rises to $\$ 1$ for especially generous taxpayers. If the credit is refundable, the negative tax liability stemming from especially generous taxpayers turns into a payment from the government to the taxpayer, and then the tax-price of giving remains constant across all ranges of generosity. 
Taxes can be designed with a variety of other donor-level restrictions, and some have been used. In the United States, a taxpayer can deduct a maximum of $60 \%$ of adjusted gross income in any year, limiting favorable tax treatment of giving for the most generous in a way that seems hard to justify. However, the excess over $60 \%$ can be carried over and deducted over the next five years, limiting the impact of the restriction to the time value of money.

The tax code includes an alternative minimum tax (AMT) payable instead of the regular income tax when the taxpayer has excessively reduced tax liability through aggressive use of all deductions and credits. The intent of the AMT is that very high-income taxpayers should not escape taxation entirely, but the devil is in the details, and the details change from time to time. Taxpayers subject to the AMT lose the right to take certain tax deductions, but under the current tax code, they retain the right to use the charitable tax deduction. Should that change, we would have an additional restriction on access to tax-price reductions. Finally, the United States has instituted partial phase-outs for specific itemized-deductions (including the charitable deduction) taken by high-income taxpayers. ${ }^{33}$

\section{How should the favorable treatment of donations be structured?}

The main question here is whether there should be a tax deduction or a tax credit for charitable donations, with several variations related to floors and ceilings and one related to the choice between seemingly equivalent tax rebates or tax matches (see also Adena 2021). But there are other forms of support, such as the checkoff system that is increasingly popular in state income taxes. Taxpayers who have over-withheld income for taxes can check a box on their state income-tax form authorizing the state to donate part of their refund to specified charities (Huffpost 2011). Some states allow the taxpayer to increase their tax liability to fund their donations through the checkoff (Tower and Angell 2007). The checkoff system does not affect the tax-price of giving; it merely saves the donor the transaction costs of donating, which may encourage modest increases in giving and/or shift giving from ineligible to eligible charities. There may still be transaction costs due to documentation requirements, which have been found to be a problem with credits and deductions (e.g., Almunia et al. 2020).

Whether government matches donations dollar for dollar or provides a $50 \%$ tax credit or a tax deduction with a $50 \%$ marginal tax rate, the results are the same - a dollar of forgone after-tax income provides the recipient with two dollars. ${ }^{34}$ The deduction and credit return money to the donor and so are called "rebates" in the literature, as opposed to matching, which adds to donations at the recipient end. Since the Tax Reform Act of 1990 and the resulting Gift Aid program, the United Kingdom allows donors to claim a combination of matches and rebates, and Almunia et al. (2020) estimate a combined price elasticity for the two. However, Eckel and Grossman conducted a series of experiments ${ }^{35}$ and concluded that when a tax break is described as government match for charitable donations, donations are higher than when the tax break is described as a tax rebate proportional to the size of the gift even though the purely economic incentives are identical in the two frames. Subsequent papers address a long list of methodological challenges, including those posed by two field experiments. Karlan and List (2007) experimented with matching and did not have a corresponding rebate frame, finding very low price-elasticities with respect to the match rate. Huck and Rasul (2011) also looked at only the matching frame and concluded that the seal of approval implicit in the choice to set up a matching fund may have been more important than the price established by the matching rate. Eckel and Grossman (2017) addressed both papers, finding that many subjects in these studies may not have paid attention to the matching scheme (described in a direct mail solicitation that subjects may have only glanced at). In the Eckel and Grossman (2017) experiment, subjects had 
to check a box indicating that they wanted their donation to be matched (some subjects donated without checking the box). They used both frames, with wordings that equalized the seal of implicit approval, and replicated their earlier findings. Overall, the evidence seems convincing, suggesting that current framing in the United States (which suggests a tax refund or rebate) is less effective than matching.

Does the difference between rebate and match elasticities reflect a framing effect (where the way something is described and not the substance of that thing affects behavior), or does it represent the structure of preferences with broader implications? Hungerman and Ottoni-Wilhelm (forthcoming) suggest the latter, detailing a theory of impure-impact giving in which donors enjoy warm glow from giving in a rebate condition but not a matching condition. Equivalentprice rebates and matches have the same impact on charitable revenues, and the warm glow and impact elements of utility interact to result in different price elasticities. They provide estimates from a natural experiment at a university in Indiana that the match-price elasticity is -1.2 and the rebate-price elasticity is -0.2 and, in the process, reject the simpler pure-impact, pure warm-glow, and impure altruism models nested in impure-impact preferences.

I have previously described the plutocratic bias inherent in progressive income taxes with a charitable tax deduction - the tax-price of giving declines as income rises. This is why advocates support replacement of the deduction with a tax credit, a reform that was adopted by Canada in $1988 .{ }^{36}$ Refundable tax credits offer tax advantages to every donor. However, transitioning to tax credits is tricky, because it is not possible to simultaneously hold tax collection and resulting total donations constant (Lindsey 1988). Reforms can be budget neutral or donation neutral but not both.

Even if the replacement is donation neutral, the pattern of giving to different nonprofit subsectors will change, because, say, a uniform tax credit of $12 \%$ produces a tax-price of giving of $\$ 0.88$ for everyone. This is an increase in price for most itemizers and a decrease in price for non-itemizers. The two groups support different kinds of charities, different kinds of charities may have different price elasticities, and the price elasticity of aggregate donations may differ between itemizers and nonitemizers. I am unaware of any studies that incorporate all these effects, but Cordes (2011) applied percentage changes to data on donations by subsector and income class from the Philanthropy Panel Study. He found that replacing deductions by a $12 \%$ nonrefundable tax credit would reduce aggregate donations by $8.7 \% .{ }^{37}$ Gifts to religion and basic needs would fall by less ( $7 \%$ and $8.1 \%)$, and gifts to arts and culture, education, health, and combined purposes fall by more than aggregate donations $(14.2 \%, 13.8 \%, 9.9 \%$, and $9.4 \%)$.

Tax credits have an additional advantage of policy independence. Any tax reform targeted at reducing marginal tax rates (the main goal of the U.S. Tax Reform Act of 1986) has the unintended side effect of reducing charitable donations under a deduction system but not under a credit system. This simplifies the task of addressing non-charity distortions caused by income taxes.

Deductions and credits may apply only to the portion of donations exceeding a specified dollar amount (such as $\$ 500$ ) or share of taxable income (such as $2 \%$ of adjusted gross income). These are called floors. Alternatively, tax relief may apply up to some specified maximum amount (a ceiling). Floors can also have multiple parts (such as a tax credit of $10 \%$ for the excess of donations over $\$ 200$ and a credit of $20 \%$ for the excess of donations over $\$ 10,000)$, and income-based phase outs can be thought of as multi-part ceilings. The key economic effect of floors and ceilings is that the marginal tax-price and the average tax-price are not constant.

Suppose we have a taxpayer who would donate $\$ 2,000$ absent tax incentives to give and $\$ 3,000$ if offered a $50 \%$ tax credit. The tax credit reduces tax payments by $\$ 1,500$ but only 


\section{Richard Steinberg}

encourages $\$ 1,000$ in added donations and is not very efficient - taxes on other taxpayers must increase by $\$ 1.50$ for each dollar donated by the first taxpayer to balance the budget. Now calculate the same numbers when there is a floor of $\$ 2,000$. To a first approximation, that taxpayer would still donate $\$ 3,000$, but the tax credit costs the government only $\$ 500$, reducing the effect on other taxpayers to $\$ 0.50$ per dollar donated. ${ }^{38}$ Intuitively, the government gets more bang for its tax expenditure buck by restricting subsidies to the margin rather than subsidizing the part that needs no subsidy. In practice, government does not know what would have been given anyway, but provided that the floor is below what most people would otherwise give, floors increase efficiency in a static model.

Should the floor be a fixed dollar amount or a percentage of income amount? When floors are provided for tax deductions, the percentage floor would better address concerns over plutocratic bias. Another consideration is accommodating differences between taxpayers in generosity. To maximize efficiency, taxpayer-specific floors would be set, but as a practical and political matter, taxpayer-specific floors cannot be used. Because income is correlated with giving, I think that a percentage floor will come closer to this theoretical ideal and do a better job restricting the subsidy to its marginal effect on giving. Finally, the behavioral economics of floors have not been extensively studied, but to the extent that the floor sends a social signal on what each donor is expected to give, a reasonable dollar-amount floor (one that most taxpayers could afford to reach) might decrease the norm of giving by higher-income taxpayers and, in a worst case, major donors would shift to giving the dollar floor amount, and less generous donors, who do not reach the floor, would stop giving altogether.

Floors look like a good idea in a static model, but in practice, we must consider dynamics. Would less generous taxpayers stop giving annually and bunch their gifts in particular years to reach the threshold and obtain tax relief? There is already considerable evidence of bunching by high-income donors, whether because they participate in intermittent capital campaigns or they wish to achieve prestige and naming rights with their gifts (Auten and Rudney (1990), but the added bunching created by floors has not been estimated.

In contrast, ceilings (a maximum amount that can be deducted or credited) make little economic sense. True, ceilings limit the government's exposure to collecting less tax money than needed in a worst-case scenario, but a capped subsidy is a waste of subsidy dollars because it mostly rewards taxpayers for gifts that they would have made without the subsidy and provides no incentive to increase donations above the capped level.

Duquette (2020) proposes a two-tiered charitable contribution tax credit for U.S. taxpayers like that adopted by Canada in 1988. Under his proposal, the first dollars donated (up to $2 \%$ of adjusted gross income) receive a $10 \%$ tax credit, and giving in excess of that threshold receives a $37 \%$ credit. Like a floor, the increasing marginal credit-rate increases bang for the buck; like a single-tier tax credit, everyone receives the same subsidy regardless of income. Generosity, rather than higher income, is rewarded by larger subsidies to giving. He simulates the effect of his proposal and various alternatives using tax data, imputing giving by non-itemizers by matching taxpayers with those surveyed in the Panel Study of Income Dynamics and simulates the effect on total giving and foregone tax collections for his proposal compared with various alternatives. Results confirm that expected total donations increase (from $\$ 290$ billion under the 2018 postreform tax law to $\$ 349$ billion if the itemized deduction is replaced by his two-tiered tax credit), while foregone tax revenues increase only slightly (from $\$ 74$ to $\$ 77$ billion). Results are even stronger when he compares the post-CARES Act law (with its non-itemizer deduction for gifts of up to $\$ 300$ ). Then giving would increase from $\$ 304$ to $\$ 349$ billion, while tax expenditures would fall from $\$ 91$ to $\$ 77$ billion. 


\section{Concluding thoughts}

There are many options for reforming the tax treatment of charitable donations, and tax design is a complicated business. One point made by Feldstein (1976) bears repeating - there is a difference between tax design (creating a tax system where there was none before) and tax reform (changing a tax system in place). There is considerable investment in charitable institutions based on the pattern of donations fostered by the current tax system, much of it irreversible. Fixing the plutocratic bias will likely result in major reductions in giving to education, the arts, and health, and wages and employment in these industries would likely decrease. To address this, reforms may need long phase-in periods, and government should consider compensating the losers through temporary income support and retraining. Current patterns of taxation are also capitalized in the value of physical assets held by nonprofits, and this is another cost of reform that government should consider helping with.

When we consider the threshold questions, the economic case for the favorable tax treatment of charitable donations is quite uneasy. Nonetheless, on noneconomic grounds, I support favorable treatment following some reforms. The argument concerns statements of civic values, fairness, and reciprocity. When a donor supports a collective good, she is helping all the free riders. Society should not cheapen the warm glow experience of donors by making giving costless, but it seems just and proper to raise taxes a bit on the free riders and use this to ease the burden on donors who sacrifice part of their personal consumption to help others. The tax authorities can make a valuable public statement that giving is valued and worthy of support.

\section{Notes}

1 Consumption taxes, like the value-added tax (VAT), tax consumer spending. The VAT is producer focused, assessed at each stage of production so that the final consumer pays the tax when purchasing goods or services. A taxpayer-focused consumption tax is administered like a personal income tax. Taxpayers report their income and savings and calculate consumption expenditures as income minus net additions to savings. In this form, charitable expenditures can receive favorable tax treatment through tax credits or deductions from the consumption base.

2 The average tax rate is taxes paid divided by income.

3 The marginal tax rate is the additional amount of tax due if income increases by one unit of currency.

4 This is the standard deduction for "married filing joint returns or qualifying widow(er)s." There are two other categories for the standard deduction and all tax brackets, but the numbers in the text will uniformly refer to married filing jointly. See IRS (2020a).

5 Twice in the history of the charitable giving tax deduction, nonitemizers could take the standard deduction and also subtract all or part of charitable donations from gross income. This is the "abovethe-line" charitable donation deduction, in effect temporarily due to the COVID-19 crisis. Currently, non-itemizers can deduct up to $\$ 300$ of donations to calculate taxable income.

6 Of course, U.S. taxes are far more complicated. Deductible donations are limited to $60 \%$ of adjusted gross income in any year. Gifts exceeding this amount receive no current tax-price reduction on the excess, but the excess can be carried over to a subsequent year and deducted then. Time donations (volunteering) are not deductible, but because volunteer time comes at the expense of after-tax labor income, the tax-price of giving an hour of time is the marginal after-tax hourly wage rate regardless of itemization status. Gifts of appreciated assets have a lower price of giving because, in addition to the charitable donation deduction, they are exempt from the capital gains tax applied to the appreciated portion of asset value. There are also complex interactions between federal, state, and local personal income taxes that cause geographic variation in the tax-price of giving, and other factors have affected the price of giving in some years.

7 The simplest linear progressive tax applies a constant marginal tax rate to income in excess of some threshold. The illustrated calculation sets the marginal tax rate to 0.3 and the threshold (top of the zero bracket) at $\$ 100$. Letting $T$ denote tax obligations, $T=0.3 \times(Y-100)$ when donations are not tax deductible, where $Y$ is income. When donations are deductible, $T=0.3 \times(Y-100-\mathrm{D})$ where $D$ is donations. 


\section{Richard Steinberg}

8 As a result of our simplifications, the fourth taxpayer's donations plus taxes add up to more than gross income, indicating a negative consumption share that would need to be financed out of savings. This is an artifact of maintaining a constant income elasticity of 2 even for high levels of income.

9 The tax-price elasticity of giving is a proportional measure of how sensitive donations are to variations in the tax-price of giving. Specifically, it is the percentage change in the level of donations resulting from a $1 \%$ change in the tax-price of giving. That elasticity is always a negative number (people buy less when the price goes up), which leads to awkward textual constructions (if elasticity is -1.2, giving is more elastic than if it is -0.6 ), so I follow convention in reporting the absolute value of elasticity in the text.

$10 \mathrm{He}$ does consider the fact that if government spending exceeds charitable giving in the absence of government spending and tax subsidies, donations will fall to zero and can fall no further. Thus, the first dollars spent by government add nothing, the last dollars add dollar for dollar, and the average bang for the buck is less than one.

11 Many economists call nonrival and nonexcludable goods "public goods" because of an older tradition where government was thought to be the sole producer. But private nonprofits also produce "public goods," so "collective" is a more accurate description.

12 Technically, the free rider problem is that the competitive Nash equilibrium of the simultaneous donations game results in under-provision of collective goods. Similar problems arise with sequential donations and donations games repeated a known number of times.

13 My exposition of both this and the optimal taxes subsections follows the wonderful exposition in Bakija (2013).

14 Wanda could value the gift above its cost ("it's the thought that counts") or below the cost ("and I dearly wish you had thought before giving me this monstrosity").

15 Technically, the subsidy is potentially Pareto-improving rather than Pareto-improving. This means that the gains to the winners exceed the loss to the losers so that it is possible to transfer money from winners to losers so that everyone benefits. It is only Pareto-improving if those transfers are made.

16 Donations themselves are a pure collective good when donor utility includes an altruistic component. The altruistic term represents concern with the outcome resulting from total donations, so if one donor increases his gift, this causes a nonrival and nonexcludable benefit to all other donors through the summation term. The only time donations are not a pure collective good is when all donors are motivated exclusively by warm glow.

17 I am not aware of empirical studies that calculate the size of external effects of giving generally. Also, warm glow suggests that the optimal Pigouvian subsidies do not need to be as large as contemplated by Pigou himself.

18 This is a reasonable assumption and would hold, for example, if the demand curve for warm glow was a downward-sloping straight line.

19 There is no consensus that Diamond's position is correct, and the detailed debate on this matter is beyond the scope of this chapter.

20 There are other market failures such as contract failure (failure to deliver the promised quality or quantity of a good when there is a particularly difficult problem of asymmetric information) and overexclusion (for excludable collective goods). The ability of nonprofits to address these market failures depends on the level of competition, and a subsidy or "cushion" for nonprofits is necessary when there is sufficient for-profit or for-profit-in-disguise competition (Steinberg, 2006).

21 Although many nonprofits need additional government and private support, they already receive it in the form of fees for service and goods from government (20.4\% of 2005 revenues for reporting public charities) and government grants (9.0\%). The largest share comes from fees for services and goods from private sources $(50.0 \%$ ), with only $12.3 \%$ of revenues coming from private donations (Blackwood et al. 2008). In addition, government directly provides many of the goods also provided by nonprofits.

22 When governments are modeled as responsive to voters, they do not always behave as social welfare maximizers. However, when the median-preference voter is decisive, as in the simplest such model of political equilibrium, government spending on the collective good is efficient when voter preferences are distributed symmetrically about the median, and any donations on top of political equilibrium would result in overprovision. See Steinberg (1987) for additional complications when voters are cognizant of voluntary donations.

23 In the provision-point mechanism, fundraising occurs in two stages. In the first stage, a goal is set (the provision point) and conditional pledges are solicited. In the second stage, donors are asked to honor their pledges if total pledges exceed the provision point and keep their money otherwise. Kickstarter 


\section{The design of tax incentives for giving}

employs a variation on this method. Provision-point mechanisms reduce free riding by pure and impure altruists, because rather than providing a small increase in total spending, their pledged donations can make an all-or-nothing difference. In the raffle mechanism, donors buy tickets that give them a probability of winning a tangible prize, and the prospect of possibly winning a prize while donating increases the incentive to give. Bose and Rabotyagov (2018) summarize empirical confirmations that these mechanisms reduce free riding and propose a combination of the two for further gains.

24 This credit is available to individuals and business entities. At first glance, this seems useless, because a tax credit is of no use to an organization that is already tax exempt, but the IRS explains why it would be beneficial to a nonprofit involved in a limited partnership for rehabilitation with a taxable entity (IRS 2020b).

25 Contract failure (fn. 19, infra) cannot be handled this way. To subsidize an activity, the activity must be observable by the tax authorities. Contract failure concerns activities that are either unobservable by the buyer/donor/client or are not third-party verifiable. For such activities, for-profits have the incentive and opportunity to deliver less than the promised quality or quantity of a good. Nonprofits are less likely to shortchange donors and consumers, but because the IRS, as a third party, cannot verify the extent of for-profit contract failure, it cannot verify the portion of nonprofit expenditures devoted to fixing this market failure (see, e.g., Steinberg 2006 for a more complete exposition and some caveats).

26 Although donor-advised funds (DAFs) existed before formal recognition in the tax code, they were first defined and regulated under Title XII of the Pension Protection Act of 2006. As discussed in a report to Congress by the U.S. Department of the Treasury (2011: 2), "The Code now defines a DAF as a fund or account at a qualified public charity . . . over which a donor or a donor-appointed advisor retains advisory privileges regarding the investment and/or distribution of assets in the account; thus the name 'donor-advised fund.' The sponsoring organization generally heeds the recommendations from the donor but is not compelled to do so." In practice, donor advice is always heeded, so the term "advised" seems like a polite fiction.

27 There are multiple subsections to the Internal Revenue Code (IRC) section 501(c) about exempt organizations. The bulk of donations go to 501(c)(3) and 501(c)(4), and the operational test for nondistribution is different across subsections. In 501(c)(3) organizations, the test is "no part of the net earnings of which inure to the benefit of any private shareholder or individual."

28 For 501(c)(3) organizations, "organized and operated exclusively for religious, charitable, scientific, testing for public safety, literary, or educational purposes, . . ., or for the prevention of cruelty to children or animals."

29 " $[\mathrm{N}]$ o substantial part of the activities of which is carrying on propaganda, or otherwise attempting, to influence legislation (except as otherwise provided in subsection (h)), and which does not participate in, or intervene in (including the publishing or distributing of statements), any political campaign on behalf of (or in opposition to) any candidate for public office."

30 IRC Section 501(m).

31 IRC Section 501(p).

32 These involve community health needs assessment, financial assistance policies, and some restrictions on billing. IRC Section 501(r).

33 During the first year of the Obama administration, the American Taxpayer Relief Act reinstated a phase out of tax deductions for individuals (couples) with income exceeding $\$ 250,000(\$ 300,000)$ that had lapsed under legislation passed by the Bush administration (Weisman 2013).

34 More generally, letting $t$ be the marginal tax rate and $m$ the match rate and $c$ the tax credit rate, if $t=c=m /(1+m)$, the tax deduction, credit, and match all produce the same price of giving.

35 The first such article is Eckel and Grossman (2003). The latest is Eckel and Grossman (2017), which contains references (omitted here) to all their other studies and studies by others.

36 The Canadian charitable tax credit is complicated. Credit can be taken for up to $75 \%$ of net income, but for gifts of certified cultural property or ecologically sensitive land, up to $100 \%$ of net income can be credited, and carryovers are available. Credits are offered at the federal and provincial level, and the credit rates vary with the size of the gift and taxable income (for example, in 2016, the federal charitable donation tax credit was $15 \%$ of the first $\$ 200$, and either $29 \%$ [for taxable income up to $\$ 200,000$ ] or $33 \%$ [for taxable income over $\$ 200,000$ ] of the excess up to gifts of $\$ 200,000$, then $29 \%$ for the remainder of gifts over $\$ 200,000$ ). Alberta added a provincial tax credit of $10 \%$ on the first $\$ 200$ and $21 \%$ on the remainder of the gift. A special bonus credit was available to first-time credit claimants in some years. (Government of Canada 2017). 


\section{Richard Steinberg}

37 These estimates assume a uniform price elasticity of -1 . He finds a different pattern when he assumes the price elasticity is -0.5 .

38 Using standard microeconomics, floors complicate donor choice. Graphically, imagine a budget line between spending after-tax income on personal consumption or donations. When there is no floor, the $50 \%$ tax credit causes the budget line to rotate outward around the personal consumption intercept, reducing the slope to -0.5 . With the floor, the budget line consists of two connected line segments. Below the floor, the slope of the budget line is -1 , but above the floor, it is -0.5 . These line segments create a nonconvex budget set, with the usual implications. There is a tangency at the kink point, but this is on a lower indifference curve than the taxpayer could reach by looking for a tangency on one or both line segments. Depending on the exact shape of the taxpayer's indifference curves, the new equilibrium could be the amount the taxpayer would give if there were no tax incentives for giving (which is lower than donations under a floorless tax credit) or an amount (depending on income effects) roughly comparable to the amount given under the floorless tax credit, or both tangencies might tie for the optimum. In terms of elasticities, nonlinearity means you have to use virtual price and virtual income changes to predict the policy impact of a tax credit. Most tax simulators used to evaluate the effect of tax reforms on charitable giving ignore these complications; the sole exception I know of is Feldstein and Lindsey (1983).

\section{References}

Adena, M., 2021. How can we improve tax incentives for charitable giving? Lessons from field experiments in fundraising. In Henry Peter and Giedre Lideikyte Huber, eds. The Routledge Handbook of Taxation and Philanthropy, forthcoming.

Almunia, M., Guceri, I., Lockwood, B. and Scharf, K., 2020. More giving or more givers? The effects of tax incentives on charitable donations in the UK. Journal of Public Economics, 183, 104114. https://doi. org/10.1016/j.jpubeco.2019.104114.

Andreoni, James, 1989. Giving with impure altruism: Applications to charity and Ricardian equivalence. Journal of Political Economy, 97(6), pp.1447-1458.

Andreoni, James, 1990. Impure altruism and donation to public goods; a theory of warm glow giving. Economic Journal, 100, pp.464-477.

Arrow, Kenneth J., 1972. Gifts and exchanges. Philosophy \& Public Affairs, pp.343-362.

Auten, Gerald and Rudney, Gabriel, 1990. The variability of individual charitable giving in the US. Voluntas: International Journal of Voluntary and Nonprofit Organizations, 1(2), pp.80-97.

Backus, Peter, 2010. Is Charity a Homogenous Good? Warwick Economic Research Paper No. 951. Warwick: University of Warwick.

Bakija, Jon, 2013. Tax policy and philanthropy: A primer on the empirical evidence for the United States and its implications. Social Research: An International Quarterly, 80(2), pp.557-584.

Blackwood, Amy, Wing, Kennard T. and Pollak, Thomas H., 2008. The Nonprofit Sector in Brief. Facts and Figures from the Nonprofit Almanac 2008: Public Charities, Giving, and Voluntering. Washington, DC: Urban Institute Press.

Blumkin, Tomer and Sadka, Efraim, 2007. A case for taxing charitable donations. Journal of Public Economics, 91(7-8), pp.1555-1564.

Bose, Bijetri and Rabotyagov, Sergey, 2018. Provision of public goods using a combination of lottery and a provision point. Journal of Behavioral and Experimental Economics, 73, pp.99-115.

Brooks, Arthur C., 2007. Income tax policy and charitable giving. Journal of Policy Analysis and Management, 26(3), pp.599-612.

Chatterjee, Chandrayee, Cox, James C., Price, Michael K. and Rundhammer, Florian, 2020. Robbing Peter to Pay Paul: Understanding How State Tax Credits Impact Charitable Giving. NBER Working Paper 27163. Cambridge: NBER.

Clotfelter, Charles T., 1985. Federal Tax Policy and Charitable Giving. Chicago: University of Chicago Press.

Clotfelter, Charles T., 1988. Tax-induced distortions in the voluntary sector. Case Western Reserve Law Review, 39, p.663.

Cordes, Joseph J., 2011. Re-thinking the deduction for charitable contributions: Evaluating the effects of deficit-reduction proposals. National Tax Journal, 64(4), p.1001.

De Wit, Arjen and Bekkers, René, 2017. Government support and charitable donations: A meta-analysis of the crowding-out hypothesis. Journal of Public Administration Research and Theory, 27(2), pp.301-319. 
Diamond, Peter, 2006. Optimal tax treatment of private contributions for public goods with and without warm glow preferences. Journal of Public Economics, 90(4-5), pp.897-919.

Duquette, Nicolas, 2020. A two-tiered charitable contribution credit for all American taxpayers. Nonprofit Policy Forum, 11(4). https://doi.org/10.1515/npf-2019-0063.

Duquette, Nicolas, Graddy-Reed, Alexandra and Phillips, Mark, 2018. The Effectiveness of Tax Credits for Charitable Giving. https://ssrn.com/abstract=3201841 or http://dx.doi.org/10.2139/ssrn.3201841.

Eckel, Catherine C. and Grossman, Philip J., 2003. Rebates and matching: Does how we subsidize charitable contributions matter? Journal of Public Economics, 87(3), pp.681-701.

Eckel, Catherine C. and Grossman, Philip J., 2017. Comparing rebate and matching subsidies controlling for donors' awareness: Evidence from the field. Journal of Behavioral and Experimental Economics, 66, pp.88-95.

Feldstein, Martin S., 1976. On the theory of tax reform. Journal of Public Economics, 6(1-2), 77-104.

Feldstein, Martin S., 1980. A contribution to the theory of tax expenditures: The case of charitable giving. In Henry J. Aaron and Michael J. Boskin, eds. The Economics of Taxation. Washington, DC: The Brookings Institution.

Feldstein, Martin S. and Lindsey, Lawrence B., 1983. Simulating nonlinear tax rules and nonstandard behavior: An application to the tax treatment of charitable contributions. In Behavioral Simulation Methods in Tax Policy Analysis. Chicago: University of Chicago Press, pp.139-172.

Government of Canada, 2017. Charitable Donation Tax Credit Rates for 2017 and 2016. https://www.canada.ca/en/revenue-agency/services/charities-giving/giving-charity-information-donors/claimingcharitable-tax-credits/charitable-donation-tax-credit-rates.html, accessed 17/11/2020.

Harbaugh, William T., 1998. What do donations buy?: A model of philanthropy based on prestige and warm glow. Journal of Public Economics, 67(2), pp.269-284.

Hossain, Belayet and Lamb, Laura, 2012. Price elasticities of charitable giving across donation sectors in Canada: Is the tax incentive effective? International Scholarly Research Notices, 1.

Huck, Steffen and Rasul, Imran, 2011. Matched fundraising: Evidence from a natural field experiment. Journal of Public Economics, 95(5-6), pp.351-362.

Huffpost (no author given), 2011. States Offer Charity 'Checkoffs' to Give Through Taxes, 23/3/2011, updated 12/6/2017. https://www.huffpost.com/entry/taxes-checkoff-for-charity_n_839868, accessed $16 / 11 / 2020$.

Hungerman, Daniel M., 2020. On the Tax Treatment of Large Charitable Gifts. Working Paper, Department of Economics. Notre Dame: University of Notre Dame.

Hungerman, Daniel M. and Ottoni-Wilhelm, Mark, forthcoming. Impure impact giving: Theory and evidence. Journal of Political Economy, preprint. https://doi.org/10.1086/713190.

Indiana Department of Revenue, 2020. Tax Credits. https://www.in.gov/dor/individual-income-taxes/ filing-my-taxes/tax-credits/, accessed 16/11/2020.

IRS, 2020a. Form 1040 U.S. Individual Income Tax Return 2019. https://www.irs.gov/pub/irs-pdf/f1040. pdf, accessed 3/11/2020.

IRS, 2020b. Tax Aspects of the Historic Preservation Tax Incentives - FAQs. https://www.irs.gov/businesses/ small-businesses-self-employed/tax-aspects-of-the-historic-preservation-tax-incentives-faqs, accessed 9/11/2020.

Kaplow, Louis, 1995. A note on subsidizing gifts. Journal of Public Economics, 58(3), pp.469-477.

Karlan, Dean and List, John A., 2007. Does price matter in charitable giving? Evidence from a large-scale natural field experiment. American Economic Review, 97(5), pp.1774-1793.

Lindsey, Lawrence B., 1988. Budget neutral options to encourage charitable giving. In Looking Forward to the Year 2000: Public Policy and Philanthropy: Spring Research Forum Working Papers. Washington, DC: Independent Sector, p.25.

Monnet, Nathalie and Panizza, Ugo, 2017. A Note on the Economics of Philanthropy. Graduate Institute of International and Development Studies Working Paper No. 19. Geneva: Graduate Institute of International and Development Studies.

Nussbaum, Martha, 2011. Creating Capabilities: The Human Development Approach. Cambridge, MA: The Belknap Press of Harvard University Press.

Ottoni-Wilhelm, Mark, Vesterlund, Lise and Xie, Huan, 2017. Why do people give? Testing pure and impure altruism. American Economic Review, 107(11), pp.3617-3633.

Ribar, David C. and Wilhelm, Mark O., 2002. Altruistic and joy-of-giving motivations in charitable behavior. Journal of political Economy, 110(2), pp.425-457.

Roberts, Russell D., 1987. Financing public goods. Journal of Political Economy, 95(2), pp.420-437. 


\section{Richard Steinberg}

Saez, Emmanuel, 2004. The optimal treatment of tax expenditures. Journal of Public Economics, 88(12), pp.2657-2684.

Steinberg, Richard, 1987. Voluntary donations and public expenditures in a federalist system. The American Economic Review, pp.24-36.

Steinberg, Richard, 2006. Economic theories of nonprofit organizations. In Walter W. Powell and Richard Steinberg, eds. The Nonprofit Sector: A Research Handbook, Second Edition. New Haven, CT: Yale University Press, pp.117-139.

Steinberg, Richard and Bilodeau, Marc, 1999. Should Nonprofit Organizations Pay Sales and Property Taxes? Washington, DC: National Council of Nonprofit Associations (out of print; contact the authors).

Surrey, Stanley, 1973. Pathways to Tax Reform: The Concept of Tax Expenditures. Cambridge, MA: Harvard University Press.

Tower, Ralph B. and Angell, Chase E., 2007. Charitable checkoffs: Taxpayer convenience or blueprint for controversy? State Tax Notes, 44(1), pp.43-50.

U.S. Department of the Treasury, 2011. Report to Congress on Supporting Organizations and Donor Advised Funds. https://www.treasury.gov/resource-center/tax-policy/Documents/Report-Donor-AdvisedFunds-2011.pdf, accessed 16/11/2020.

Weisman, Jonathan, 2013. Senate Passes legislation to allow taxes on affluent to rise. The New York Times, 1.1.2013.

Vickrey, William S., 1947. Agenda for Progressive Taxation. New York: Ronald Press Company.

Vickrey, William S., 1962. One economist's view of philanthropy. In Frank G. Dickinson, ed. Philanthropy and Public Policy. Cambridge, MA: NBER, pp.31-56.

Zampelli, Ernest M. and Yen, Steven T., 2017. The impact of tax price changes on charitable contributions to the needy. Contemporary Economic Policy, 35(1), pp.113-124. 